\title{
Equality and Diversity in Education ${ }^{1}$
}

Ted Fleming, NUI Maynooth

\section{INTRODUCTION}

In 1347 the King of France, Philip VI, ordered the City of Calais to hold out against the English under Edward III. Philip failed to lift the siege and starvation eventually forced the people to surrender to the English. Edward offered to spare the city if any six leaders would give themselves up, presumably to be hanged. Six of the wealthiest burghers of Calais volunteered and walked out almost naked to face certain death - in 1888 Auguste Rodin celebrated their bravery in a wonderful bronze sculpture. Philippa, the wife of Edward, pleaded on their behalf and they were spared. It would have been, she said, a bad omen for her and the child to whom she was about to

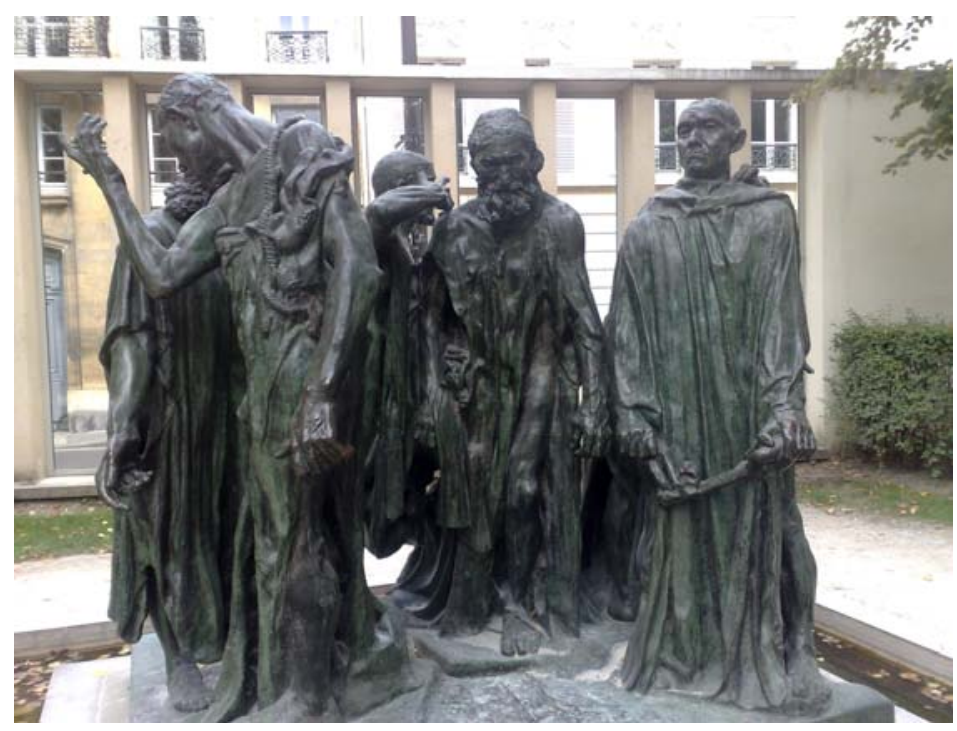
give birth.

Two discourses were expressed in these events over 650 years ago: the discourse of the king with its talk of war, treaties, death and procedures; and the discourse of the queen talking about mercy and people, with everything taking second place to the welfare of the child. Two similar discourses continue to thrive in our conversations today. I will take an example from three years ago in order not to be controversial, even though we could find more recent examples.

I would like to quote you a news flash that was broadcast during the Junior Certificate exam period in 2005:

A school in Navan, where four of the five schoolgirls killed in last month's school bus crash were pupils, has said there was shock in the school over a question on a Junior Certificate paper today. An essay topic in the Junior Cert. Ordinary Level English paper was entitled 'Travelling on the School Bus'. A spokesperson for the Loreto Convent Secondary School in Navan said there was 'a deep sense of shock' there over the question. The Minister for Education, Mary Hanafin, said she would be talking to the Exams Commission, which has responsibility for setting papers, as soon as possible. (RTÉ News, 8 June 2005, 5.30 p.m.)

All of what I want to say today is sedimented in these stories. In the Navan story, as with the original bus crash, there are two discourses, two languages being spoken. There is the language of the system and the language of the people. One language

\footnotetext{
${ }^{1}$ An abridged version of this paper was published in The Equality Authority (Eds.) Equality in a Time of Change: Mainstreaming equality in FE, training and labour market programmes, (pp.42-47).

Dublin: The Equality Authority.
} 
speaks of deep shock. The other, the language of the system, talks of the Exams Commission.

After the original crash in which five people died, the families and the wider community spoke about the nightmare that every parent dreads, the unspeakable sadness of losing a child and of how the people, as a community, would have to dig deep into their souls to support each other.

The system spoke a different language. When people asked about seat belts on buses, the system replied:

We have the safest school bus service in Europe.

Statistically our children are safer in school buses than in cars.

We have spent $€ 13$ million on renewing school buses in the past decade.

We will over the coming two years renew our school fleet so that all buses are capable of having seat belts installed.

There is no evidence that seat belts would have saved any lives ...

This discourse is also about how the system can, at all costs, avoid blame. These are distancing answers that speak in the language of the system, empty of concern and care and full of incompetence. They are met with incomprehension by a community that wants someone to say:

We have been able to find $€ 50$ million for an electronic voting system that may never work, and we will, by next September, have buses in such a condition that no parent will feel their child is at risk when the state takes over the care of your children each morning.

The bottom line in system speak is about procedures, regulations, costs, a preoccupation with policies and guidelines and a rejection of emotional arguments. The bottom line in people speak is about care, concern, mercy, compassion, relationships and an embracing of emotional reactions and feelings.

\section{THE EDUCATOR'S ROLE}

Educators and trainers work in the tension between the language of productivity and the language of care, between the values of throughput and efficiency on the one hand and giving someone the time they need to learn and grow on the other.

Of course, not all system speak is wrong and flawed and not all people speak is unproblematic. For example, it is the system that enshrined the Employment Equality Acts and the Equal Status Acts. Problems arise, however, when one discourse is used inappropriately or when one discourse is ignored, excluded or not acknowledged at all.

To bring our debate up to date it seems to me that one of the great skills of Barack Obama has been his ability to speak both the language of the system and the language of care and people. He has been able to transcend the different discourses of system speak and people speak. He has spoken to crowds of 40,000 people in forensic detail about economics, tax proposals and redistribution of wealth while at the same time 
continuing to engage, unite and demonstrate concern and care. People speak and system speak have become integrated and connected to each other and people have responded. In a democracy, people speak is the more important because at its best the system should institutionalise people speak.

Educators and trainers inhabit the territory between the system world and the people world. Regulations, laws, targets, procedures, keeping account of clients, tracking, quality assurance - this is all system stuff. We are paid by the system. Supporting learners and dealing with the always complex human dilemmas and challenges of becoming more adult and more human through learning is people stuff.

The system demands, and rightly so, that policies and procedures are in place that agree with the requirements of the law on equality, diversity and equal status. Training programmes and monitoring of procedures and practices are essential activities in the implementation of these public policy priorities. The equality agenda that is enshrined in these laws has also put systems in place for vindicating people's rights when they are violated on any of the nine grounds of gender, marital status, family status, sexual orientation, religion, age, disability, race or membership of the Traveller community.

More is needed because the system merely lays down minimum requirements and objective criteria. People speak requires something different and it emphasises that attitudes and mindsets are crucial too. The system, the law, is not the best way to change minds and attitudes so the additional responsibility falls on educators not only to have the systems in place but also to make sure that our heads and hearts are in tune with the equality and diversity agenda. In educational speak there is a responsibility to ensure that the hidden (and not so hidden) curriculum is also infused with equality.

The system would be happy if we obeyed the law. The ethic of care that I have attempted to identify and articulate speaks not only of following the letter of the law, though that is required, but also of prioritising an ethic of care that is only imperfectly enshrined in the laws.

But eliminating harassment and victimisation from all areas of work and society, making reasonable accommodation for difference, making discrimination a historical memory and encouraging positive action are all major challenges that face us not just as a system imperative but as a human imperative. They involve accepting, for example, people with a disability into our classes not just because this is the law and the requirement but because we as teachers share with them a common humanity. The core of all discrimination rests on ascribing less humanity to those discriminated against.

The challenge for educators and trainers is complex. It requires that we operate within the legal framework and that we relate to all who are different in a careful manner. The implications are twofold. There is a responsibility to learn about the legal and system requirements and an equal need to learn how to operate an ethic of care. In old-fashioned speak, there is a dual mandate to operate legally and morally.

The onus is on us as educators to first of all change ourselves and not only become familiar with the minimal system and procedural requirements but undergo a transformation, if one is required, in thinking, attitudes and understanding of the importance of equality, difference and care. 
The system imperative for our sector in adult education and training, with its hugely diverse contexts and situations in which learning occurs, is to ensure that discrimination is not only dealt with appropriately but that it is prevented across the nine grounds.

The practices, policies, culture and ethos of the training context must be constantly reviewed and reformed. Training the trainers is the password for good practice. The precondition for being able to accept and work with diversity is an openness to change by providers and staff. We are constantly in danger of not getting it right, of misunderstanding what is required, but the insurance against this is the openness to change that is only learned.

We do have to learn our way through the fast-changing world where equality and diversity as policy priorities are evolving as we meet and confront new and different situations. To become more egalitarian and inclusive will only be achieved by learning. Too often the hope is expressed that policies and practices need to be disseminated and enforced. Indeed they do, but the onus is on the leadership of these activities to see that only through learning will the initiatives be rooted in more than systems and rooted in the minds and hearts of those we wish to be more egalitarian and inclusive.

It is not about just following the law, it is about changing people's minds and hearts. Commitment to equality in the workplace, enforcement and implementation are important but the main priority is to ensure that attitudes are changed.

\section{EQUALITY AND DIVERSITY IN EDUCATION}

Apart from all the imperatives from the system and the law there is another even more crucial reason why equality and diversity matter in education. And it is not derived from the legal requirements or from the system. This reason does not come from outside education at all. The reason why equality and diversity matter comes from within education itself.

At the heart of education there is the valuing of equality. In the best of philosophy of education there is the valuing of equality. Whether it is Paulo Freire or John Dewey, the idea that one respects the learner and each other is the precondition for any educational activity.

Furthermore, without difference there can be no learning. If we all agreed on everything, learning would be impossible. It is only when cognitive dissonance, disagreement and difference are about that we can change and learn. All the best educators have embraced difference as the precondition for any kind of significant learning. Differences in, for example, gender, family status, age, religion or sexual orientation challenge one's own understandings and provide a welcome opportunity to expand the horizons within which we think, feel, act and relate to others. As educators we need difference, it is the precondition for learning

The burghers of Calais were saved when the language of care triumphed over the language of the system, however, educators add a third set of imperatives. Educators are engaged, as is appropriate in a more complex world, in a set of three languages: of the system, of care and of our own discipline of education. 